\title{
FERTILITAS DAN PERSENTASE EMBRIO KERBAU SAMPAI MORULA YANG DIKULTUR DENGAN PENAMBAHAN GLUTATHIONE SECARA IN VITRO
}

\author{
HARISSATRIA DAN J.HENDRI \\ Jurusan Peternakan \\ Fakultas Pertanian Universitas Mahaputra Muhammad Yamin \\ Email: haris_satria85@yahoo.com
}

\begin{abstract}
The concentration of high fat content in buffalo embryo culture media is very influential on the increase in oxidative stress that occurs in conditions of in vitro. The occurrence of increased oxidative stress in the process of embryo culture in vitro, would result in lower percentage of embryo culture until the morula stage (32) cells. The purpose of this study was to determine the percentage of fertilized oocytes supplemented with glutathione. To know the development of the embryo until the morula stage (32) cells were cultured in the culture medium supplemented with glutathione (GSH). To determine the viability of morula stage embryo or 32 cells. The materials used in this study is ovarian buffaloes and methods used in this study is an experimental method in the laboratory. Based on these results it can be concluded that the addition of glutathione $1.5 \mathrm{mM}$ in media oocyte maturation buffalo in vitro provide a significant influence on the percentage of maturation ie $(P<0: 01)$ or $62.5 \%$ and in line with the high percentage of oocytes matured in treatment increase glutathione $1.5 \mathrm{mM}$, then the percentage of oocytes were successfully fertilized also higher, namely 88.98\%. Furthermore, the addition of $3 \mathrm{mM}$ glutathione in embryo culture media in vitro buffalo give a significant influence on the percentage of embryo development to the morula stage or cell 32 , namely $(P<0.01)$ in, or $40.73 \%$.
\end{abstract}

Keywords: culture, embryo, buffalo, glutathione, in vitro

\section{PENDAHULUAN}

Proses produksi embrio secara in vitro memerlukan lingkungan mikro yang dapat mendukung pertumbuhan dan perkembangan embrio. Tissue culture medium (TCM)-199 merupakan media komplek yang bersifat komersial dan telah digunakan untuk produksi embrio in vitro seperti pada sapi (Boediono et al., 2003) dan domba (Jaswandi et al., 2001). Tissue culture medium (TCM) 199 yang secara luas digunakan untuk pertumbuhan embrio dari hewan dan ternak (Boediono et al., 1995; Djuwita et al., 1995). Berbagai hasil pematangan dengan media TCM-199 tersebut sudah dilaporkan secara luas oleh para peneliti dengan hasil yang memuaskan (Palazs et al., 2000). Oosit pada media berbahan dasar TCM 199 mampu untuk difertilisasi dan melakukan tingkat pembelahan awal (cleavage) dengan sempurna meskipun jumlah perkembangan embrio awal lebih sedikit dibandingkan dengan pada media rutin dengan persentase masing-masing adalah 23,2 dan 44,4\% (Setiadi dan Ni Wayan, 2013).
Ditinjau dari aspek fisiologis, oosit dan embrio kerbau mengandung kadar lemak yang tinggi selama proses maturasi dan selama proses kultur embrio secara in vitro (Boni et al., 1992). Konsentrasi kadar lemak yang tinggi pada oosit dan media kultur embrio kerbau secara in vitro, sangat berpengaruh dan sensitif terhadap peningkatan stres oksidatif yang terjadi dalam kondisi in vitro (Gasparrini et al., 2003).

Glutathione (C10,H17,N3O6S) dan derivatnya yang merupakan tri-peptida (y-Glu-Cys-Gly) dapat mempengaruhi banyak aspek metabolisme, diantaranya membantu detoksifikasi dan transport dari y-glutamilamino acid, sehingga diharapkan dapat meningkatkan persentase fertilisasi in vitro yang pada akhirnya bisa meningkatkan persentase embrio sampai morula dan blastosis (De Matos dan Furnus, 2000). Selanjutnya Intracellulair glutathione (GSH) dapat meningkatkan clevage rate dan perkembangan embrio sampai blastosist dan GSH yang tinggi membantu proses maturasi in vitro, dan tetap tersedia saat fertilisasi in vitro dan 
pada awal perkembangan embrio sampai 6-8 sel. (De Matos dan Furnus, 2000). Tujuan dari penelitian ini untuk mengetahui persentase oosit kerbau yang terfertilisasi setelah penambahan glutathione, mengetahui viabilitas embrio kerbau yang membelah dan sampai tahap morula atau 32 sel.

\section{MATERI DAN METODE}

Ovarium kerbau sebagai sumber oosit dikoleksi dari Rumah Potong Hewan $(\mathrm{RPH})$ kota Padang. Ovarium dibawa ke laboratorium Bioteknologi Ternak Universitas Andalas dengan termos berisi media fisiologis $\mathrm{NaCl} 0,9 \%$ bersuhu sekitar $35^{\circ} \mathrm{C}$. Sampai di laboratorium ovarium dicuci dengan PBS (Phosphate Buffered Saline), oosit diaspirasi dari folikel berukuran 2-5 $\mathrm{mm}$ dalam media PBS (Phosphate Buffered Saline) menggunakan spuit 10cc dan jarum suntik berukuran 18G. Setelah aspirasi dilakukan pengirisan untuk mencari oosit yang masih tinggal dalam media kemudian dibilas dengan media PBS dan ditampung dalam cawan petri berdiameter $5 \mathrm{~cm}$ dan dipindahkan dalam cawan petri di bawah mikroskop menggunakan pipet pasteur steril. Oosit yang mempunyai sitoplasma homogen dan beberapa lapis kumulus dimatangkan dalam 3 macam medium yaitu medium Tissue Culture Medium 199 (TCM 199) yang mengandung $1 \mathrm{mM}, 2 \mathrm{mM}$ dan $3 \mathrm{mM}$ Glutathione (GSH) sebagai perlakuan. Ketiga medium juga disuplementasi dengan FSH, serum dan gentamicin. Pematangan in vitro dilakukan dengan inkubasi oosit dalam inkubator $\mathrm{CO}_{2} 5 \%$ bersuhu $38,5^{\circ} \mathrm{C}$ dan kelembaban $90 \%$ selama 24 jam.

Oosit yang telah mengalami pematangan dalam setiap perlakuan A, B dan C, dicuci dengan media TCM-199 dua kali dan sekali dalam medium fertilisasi, kemudian ditempatkan dalam media Tyrode's albumin lactate pyruvate (TALP) $5 \mathrm{ml}$. Oosit difertilisasi menggunakan spermatozoa dari epididimis kerbau dengan konsentrasi $1 \times 10^{6}$ spermatozoa. Oosit bersama spermatozoa diinkubasi selama 18 jam dalam inkubator $\mathrm{CO}_{2} 5 \%$. Oosit dicuci dengan media TALP untuk menghilangkan sel-sel komulus dan dihitung jumlah oosit terfertilisasi pada masing-masing perlakuan. Selanjutnya pada hari kedua dilakukan kultur embrio sampai tahap morula (32) sel dengan perlakuan konsentrasi GSH dalam media kultur. Peubah yang diamati adalah persentase oosit kerbau terfertilisasi dengan penambahan glutathione (GSH) secara in vitro dan persentase embrio yang berhasil berkembang sampai tahap morula atrau 32 sel. Metode yang digunakan adalah eksperimen dan rancangan yang digunakan adalah Rancangan Acak Kelompok (RAK) dengan 3 perlakuan dan 6 ulangan sebagai kelompok. Data yang diperoleh dianalisa secara statistik dengan menggunakan sidik ragam (Analysis of Variance/ANOVA).

\section{HASIL DAN PEMBAHASAN}

\section{Persentase Oosit Kerbau Terfertilisasi pada Penambahan Gluthatione}

Persentase oosit kerbau yang berhasil difertilisasi dengan penambahan glutathione pada masing-masing perlakuan diperlihatkan pada perlakuan $1,5 \mathrm{mM}$ dengan persentase $88,98 \%$ dan dapat dilihat dari Tabel 1.

Tabel 1. Persentase oosit kerbau terfertilisasi pada penambahan Gluthatione

\begin{tabular}{lcc}
\hline \multicolumn{1}{c}{ Perlakuan } & $\mathrm{N}$ & Persentase Oosit Kerbau Terfertilisasi (\%) \\
\hline A (0.5 Gluthatione) & 67 & $47.60^{a}$ \\
B (1.0 Gluthatione) & 89 & $48.50^{a}$ \\
C (1.5 Gluthatione) & 132 & $88.98^{b}$ \\
\hline
\end{tabular}

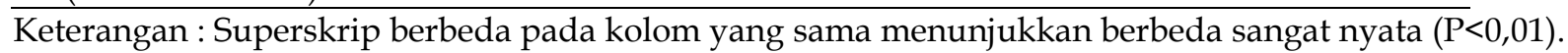


Hasil penelitian menunjukkan penambahan gluthatione $1,5 \mathrm{mM}$ dalam media maturasi oosit kerbau secara in vitro menghasilkan persentase oosit terfertilisasi sangat nyata $(\mathrm{P}<0,01)$ lebih tinggi dibandingkan maturasi dengan penambahan gluthatione $0,5 \mathrm{mM}$ dan 1,0 mM. Sedangkan persentase fertilisasi oosit kerbau dengan penambahan gluthatione $0,5 \mathrm{mM}$ dan $1,0 \mathrm{mM}$ tidak menunjukkan perbedaan yang nyata $(\mathrm{P}>0,05)$. Hal ini berarti penambahan gluthatione 1,5 mM dalam media maturasi oosit kerbau cukup efektif untuk meningkatkan keberhasilan fertilisasi oosit kerbau secara in vitro. Hal ini diduga peranan penambahan gluthatione sangat penting dilakukan pada saat maturasi oosit kerbau secara in vitro. Pada saat maturasi oosit kerbau secara in vitro, gluthatione berfungsi menekan stress oksidatif yang disekresikan oleh sel-sel dan oosit pada saat pematangan sehingga pada waktu oosit difertilisasi dengan spermatozoa cauda epididimis, maka akan semakin tinggi tingkat keberhasilan fertilisasi secara in vitro.

Hasil penelitian ini sesuai dengan hasil yang dikemukakan oleh Urdaneta et al., (2003) bahwa penambahan 1,0 mM GSH dalam media fertilisasi meningkatkan angka fertilisasi dari $10,61 \%$ menjadi $30,20 \%$ dibandingkan dengan tanpa penambahan GSH pada oosit kambing prepubertas. Lebih lanjut Kim et al., (1999) juga melaporkan penambahan $1 \mathrm{mM} \mathrm{GSH}$ dalam media fertilisasi, jumlah embrio sapi yang mencapai tahap blastosis lebih tinggi (27,3\%) dibandingkan dengan $0 \mathrm{mM}$ $(20,1 \%), 0,1 \mathrm{mM}(21,8 \%)$ dan $10 \mathrm{mM}$ (8,9\%). Selanjutnya Maedomari et al., (2007) menyatakan GSH yang terdapat pada sitoplasma oosit berperan dalam proses pembentukan pronukleus dimulai dari pemecahan ikatan disulfide membran inti yang dilanjutkan dengan inisiasi dekondensasi kromosom. Lebih lanjut Zuelke et al., (2003) menjelaskan pada oosit yang matang, GSH mempunyai peran penting dalam pembentukan pronukleus jantan setelah fertilisasi. Lee et al., (2003) menjelaskan faktor utama yang mengakibatkan kegagalan pembentukan pronukleus jantan setelah intracytoplasmic sperm injection (ICSI) pada oosit babi adalah konsentrasi GSH. Konsentrasi GSH dalam sitoplasma oosit hasil pematangan in vitro tergantung pada kondisi awal proses pematangan yang ditentukan oleh keberadaan sel-sel komulus. Konsentrasi GSH dalam oosit menunjukkan tingkat kematangannya dan GSH memengaruhi keberhasilan dan perkembangan embrio selanjutnya (Maedomari et al., 2007). Lebih lanjut dijelaskan di bawah kondisi fisiologi, level GSH tinggi pada oosit tikus dan hamster, penting untuk pembentukan pronukleus jantan setelah fertilisasi dan mendukung perkembangan embrio dini (Zuelke et al., 2003).

Rendahnya angka fertilisasi pada perlakuan $0,5 \mathrm{mM}$ dan 1,0mM GSH adalah tidak semua oosit telah mencapai stadium metaphase II, pada saat setelah difertilisasi tidak semua oosit dapat melakukan pembelahan dengan sempurna. Menurut De Matos dan Furnus (2000), glutathione dapat meningkatkan laju pembelahan atau cleavage rate dan perkembangan embrio sampai tahap blastosis, selanjutnya dijelaskan penggunaan glutathione pada media fertilisasi dapat meningkatkan penetrasi spermatozoa pada saat fertilisasi in vitro, sehingga diharapkan dapat meningkatkan keberhasilan fertilisasi in vitro yang pada akhirnya dapat meningkatkan kualitas dan kuantitas blastosis yang dihasilkan.

\section{Persentase Embrio yang Berhasil Berkembang sampai Morula}

Persentase oosit kerbau yang berhasil berkembang sampai tahap morula atau 32 sel dengan penambahan glutathione pada masing-masing perlakuan diperlihatkan pada perlakuan $3 \mathrm{mM}$ dengan persentase $40,73 \%$ dan dapat dilihat dari Tabel 2 : 
Tabel 2. Persentase embrio morula pada berbagai penambahan Gluthatione

\begin{tabular}{ccc}
\hline Perlakuan & $\mathrm{N}$ & Persentase Kultur Embrio 32 sel (\%) \\
\hline A (1 mM Gluthatione) & 269 & $23.87^{a}$ \\
B (2 mM Gluthatione) & 269 & $28.21^{a}$ \\
C (3 mM Gluthatione) & 269 & $40.73^{b}$ \\
\hline
\end{tabular}

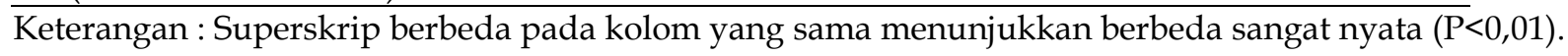

Hasil penelitian menunjukkan penambahan gluthatione $3 \mathrm{mM}$ dalam media kultur embrio kerbau secara in vitro menghasilkan persentase perkembangan embrio sampai tahap morula sangat nyata $(\mathrm{P}<0,01)$ lebih tinggi dibandingkan kultur embrio dengan penambahan gluthatione $1 \mathrm{mM}$ dan $2 \mathrm{mM}$ GSH. Sedangkan persentase kultur embrio kerbau sampai tahap morula dengan penambahan gluthatione $1 \mathrm{mM}$ dan $2 \mathrm{mM}$ GSH tidak menunjukkan perbedaan yang nyata $(\mathrm{P}>0,05)$. Hal ini berarti penambahan gluthatione $3 \mathrm{mM}$ dalam media pematangan oosit kerbau cukup efektif untuk meningkatkan keberhasilan kultur embrio kerbau sampai tahap morula secara in vitro.

De Matos et al., 2002; Gasparrini et al., 2003; Beheshti et al., 2011, bahwa media kultur embrio in vitro yang mengandung prekursor GSH seperti cysteamine dan $\beta$-mercaptoethanol akan meningkatkan kandungan GSH dan memiliki efek yang menguntungkan pada perkembangan embrio 8 sel sampai tahap blastosit. Menurut yang dinyatakan oleh de Matos et al., 2002 dan Songsasen et al., 2002, bahwa suplementasi senyawa tiol akan meningkatkan sistesis GSH dalam media kultur dan meningkatkan kualitas embrio kerbau yang di kultur semakin baik. Menurut Gasparrini et al., 2003, oosit kerbau yang dikultur secara in vitro dapat mensintesis GSH secara kimiawi. GSH adalah nonprotein sebuah senyawa sulphydryl dan memainkan peran penting dalam melindungi sel mamalia dari stres oksidatif dan sintesis intraseluler yang sangat penting dalam kultur embrio
(Gordon, 2003; Gasparrini et al., 2003; Ruder, 2008).

Kim et al., (2004) melaporkan glutathione (GSH) memiliki banyak fungsi seperti dalam mempertahankan reaksi redoks dalam sel yang dikultur, meningkatkan pembentukan pronukleus jantan, protein dan sintesis DNA, dan pengurangan disulfifi des. Konsentrasi GSH akan meningkat selama pematangan oosit dalam ovarium, yang digunakan untuk perlindungan sel dalam langkahlangkah perkembangan selanjutnya (Beheshti et al., 2011). Selanjutnya penambahan bahan yang bermanfaat seperti gonadotropin, estradiol, faktor pertumbuhan (Vahedi et al., 2009) dan antioksidan (Balasubramanian dan Rhob, 2007) diperlukan untuk perkembangan embrio in vitro.

\section{Persentase Viabilitas Embrio yang Berhasil sampai Tahap Morula}

Kemampuan embrio yang di kultur dalam penambahan GSH $3 \mathrm{mM}$ menunjukkan persentase perkembangan embrio dari 2 sel, 4 sel, 8 sel, 16 sel dan 32 sel semakin menurun sampai tahap morula yaitu $93,77 \%$; 82,19\%; 73,43\%; $54,78 \%$ dan $40,73 \%$. Menurunnya persentase perkembangan embrio dari 2 sel sampai tahap morula disebabkan oleh viabilitas dari embrio yang di kultur yang berbeda-beda serta faktor penggantian media kultur yang diganti satu kali 2 hari.

Edwards et al., 1997, menyatakan persentase tertinggi kultur embrio 2 sel adalah $83,21 \%$, persentase kultur embrio sampai tahap morula adalah $33,26 \%$ dan 
sampai hari ke 9 semakin menurun yaitu $15,12 \%$. Semakin menurunnya persentase perkembangan embrio sampai tahap morula karena embrio tahap morula lebih sensitif terhadap perubahan lingkungan karena kemampuan transcriptionally quiescent terbatas untuk merespon perubahan lingkungan. Trounson et al. (1994) menyatakan embrio sapi menggunakan asam asetat lebih banyak pada perkembangan awal embrio dibanding perkembangan akhir embrio.

Rataan persentase morula yang dihasilkan dalam penelitian ini hampir sama dengan hasil penelitian Kim et al. (1999) yang menyatakan glutathione yang ditambahkan dalam medium fertilisasi sejumlah 0-1,0 $\mathrm{mM}$ akan membantu pembentukan morula dari $20,10 \%$ menjadi $27,30 \%$. Hal ini mengindikasikan perlakuan penambahan glutathione pada medium fertilisasi membantu mempertahankan perkembangan embrio dari stadium pembelahan oosit ke stadium morula dengan cara mencegah kemungkinan terjadinya radikal bebas akibat perubahan kimiawi pada medium fertilisasi serta membantu detoksifikasi dari kemungkinan kontaminasi jasad renik yang masuk ke dalam medium.

Persentase perkembangan embrio in vitro 2 sel $(93,77 \%)$ dan morula $(40,73 \%)$ pada medium kultur yang di tambah GSH pada penelitian ini ternyata lebih tinggi dari pada hasil penelitian Keskintepe et al. (1995) yang menggunakan medium kultur SOF dengan perolehan pembelahan, blastosist dan expanded blastocyst masingmasing $66,3 \% ; 10,9 \%$ dan $3,3 \%$. Tetapi bila kedalam medium SOF tersebut ditambahkan sitrat dan NEAA, pembelahan meningkat menjadi $85,1 \%$, blastosist $42,6 \%$ dan expanded blastocyst $16,8 \%$, lebih tinggi dibandingkan hasil penelitian ini yang dikultur dalam KSOM. Namun hasil tersebut masih lebih rendah dibandingkan embrio yang dikultur di dalam medium CR1aa, dengan persentase pembelahan, blastosist dan expanded blastocyst pada penelitian ini berturutturut adalah $91,4 \% ; 61,5 \%$ dan $31,2 \%$.

\section{KESIMPULAN}

Penambahan Glutathione 1,5 mM pada media maturasi oosit kerbau secara in vitro memberikan peningkatan terhadap persentase angka maturasi yaitu $(\mathrm{P}<0,01)$ atau $62,5 \%$ dan seiring dengan tingginya persentase oosit yang matang pada perlakuan penambahan glutathione 1,5 mM, maka persentase oosit yang berhasil terfertilisasi juga semakin tinggi yaitu $88,98 \%$ dan menghasilkan perkembangan embrio sampai tahap morula sebesar $40,73 \%$.

\section{DAFTAR PUSTAKA}

Balasubramanian S, Rhob G. J. (2007). Effect of cysteamine supplementation of in vitro matured bovine oocytes on chilling sensitivity and development of embryos. Anim. Reprod. Sci. 98: 282-292.

Beheshti, R., Mohammadi-Roshandeh, A., Giasi Ghalehkandi, J., Ghaemmaghami, S. and Houshangi, A.F. 2011. Effect of antioxidant supplements on in vitro maturation of bovine oocyte. Advanced Environmental Biology, 5: 1473- 1475.

Boediono A, Rajamahendran A, Saha S, SO Imantri C, and Suzuki T. 1995. Elect of the presence of a CL in the ovary on oocyte rutmber, cleavage rate and blastocyst production in vitro in cattle. Theriogenology 43 :169 (Abst).

Boediono A, Suzuki T, Godke R. 2003. Comparison of hybrid and purebred in vitro-derived cattle embryos during in vitro culture. Anim Reprod Sci 78:1-11.

Boni, R., Sangella, L., Dale, B., Rovello, S., Di Palo, R., Barbieri, V., 1992. Maturazione in vitro di oociti bufalini: indagine ultrastrutturale. Acta Med. Vet. 38:153-161. 
De Matos D.G. and C.C. Furnus. 2000.The importance of having high glutathione (GSH) level after bovine in vitro maturation on embryo development. Effect of betamercaptoethanol, cystein and cystine. Theriogenology 53:761-771.

De Matos DG, Gasparrini B, Pasqualini SR, Thompson JG. 2002. Effect of glutathione synthesis stimulation during in vitro maturation of ovine oocytes on embryo development and intracellular peroxide content. Theriogenology 57: 1443-1451

Djuwita, I., B. Purwantara, M. Fahrudin and Y. Sukra. 1995. The effect of superovulated cow serum on in vitro maturation and fertilization in sheep. Pros. Symposium on Biotechnology of Animal Reproduction, Bogor. hlm. 20-22.

Edwards, J. L., A. D. Ealy, V. H. Monterroso and P.J.Hansen. 1997. Ontogeny of temperature-regulated heat shock protein 70 synthesis in preimplantation bovine embryos. Molecular Reproduction and Development 48:25-33.

Gasparrini B, Sayoud H, Neglia G, de Matos DG, Donnay I, Zicarelli L (2003). Glutathione synthesis during in vitro maturation of buffalo (Bubalus bubalis) oocytes: effects of cysteamine on embryo development. Theriogenology, 60: 943-952.

Gordon, I. 2003. Laboratory of Cattle Embryos Second Edition. CABI Publishing, London.

Jaswandi, A. Boediono and M.A.Setiadi. 2001. In vitro maturation and fertilization of sheep oocytes in absences $\mathrm{CO}_{2}$. Reprotech Journal. $1: 56-60$.

Keskintepe, L., C.A. Burnley and B. G. Brackett. 1995. Production of viable bovine blastocysts in defined in vitro conditions. Biol. of Reprod. 52:1410-1417.

Kim I.H., A Van Langendockt, A. Van Soom, G. Van Roose, A.L.Casi, P.J.M. Hendriksen. and M. Bevers. 1999. Effect of exogenous glutathione on in vitro fertilization of bovine oocytes. Theriogenology. 52:537- 547.
Kim, M. K., H.Y. Fibrianto, H. J. Oh, G. Jang, H. J. Kim, K. S. Lee, S. K. Kang, B. C. Lee W. S. Hwang (2004): Effect of $\beta$ mercaptoethanol or epidermal growth factor sementation on in vitro maturation of canine oocytes collected from dogs with different sages of the estrus cycle. J. Vet. Sci. 5, 253-258.

Lee, J., X.C. Tian, and X. Yang. 2003. Failure of male pronucleus formation is the major cause of lack of fertilization and embryo development in pig oocytes subjected to intracytoplasmic sperm injection. Biol. Reprod. 68:1341-1347.

Maedomari, N., K. Kikuchi, M. Ozawa, J. Noguchi, K. Ohmuna, M. Nakai, M. Shino, T. Nagai, and N. Kashiwazaki. 2007. Cytoplasmic glutathione regulated by cumulus cells during procine oocyte maturation affects fertilization and embryonic development in vitro. Theriogenology. 67:983-993.

Palazs, A.T., J. Thundathil, R.E. Verrall, and R.J. Mapletoft. 2000. The effect of macromolecular supplementation on the surface tension of TCM-199 and the utilization of growth factors by bovine oocytes and embryos in culture. Anim. Reprod. Sci. 58: 229-240.

Ruder, E.H., Hartman, T.J., Blumberg, J. and Goldman, M.B. 2008. Oxidative stress and antioxidants: exposure and impact on female fertility. Human Reproduction Update, 14:345-357.

Songsasen, N. and Apimeteetumrong, M. 2002. Effects of $\beta$-mercaptoethanol on formation of pronuclei and developmental competence of swamp buffalo oocytes. Animal Reproduction Science, 71:193-202.

Setiadi. M. A., dan Ni Wayan. K. K. 2013. Tingkat Perkembangan Awal Embrio Sapi In Vitro Menggunakan Media Tunggal Berbahan Dasar Tissue Culture Medium (TCM) 199. Jurnal kedokteran hewan. 7(2).

Trounson, A., D. Pushett, L.J. Machellan, I. Lewis and Gardner. 1994. Current status of IVM/IVF of embryos culture in human and farm animal. Theriogenology 42: 1153-1171. 
Triwulanningsih, Ejoelihere M.R, Yusuf T.L, Purwantara B, Diwiyanto K, Rutledge J.J .2001 a. Seleksi dan kapasitasi sperma dengan metode Percoll gradient untuk fertilisasi oosit dan produksi embrio in vitro sapi . Unpublished.
Vahedi V, Zeinoaldini S, Kohram H, Farahavar A. 2009. Retinoic acid effects on nuclear maturation of bovine oocytes in vitro. Afr. J. Biotechnol. 8(16): 3974-3978.

Zuelke K.A., S.C. Jeffay, R.M., Zucker, S.D., Perreault, 2003. Glutathione (GSH) concentrations vary with the cell cycle in maturing hamster oocytes,zygotes and preimplantation stage embryos. Mol Reprod Dev 64:106-112. 